\title{
Penapisan Virtual Senyawa Dalam Tanaman Familia Annonaceae Sebagai Ligan Pada Reseptor Estrogen Alfa (ER- $\alpha)$
}

\author{
Esti Mulatsari ${ }^{1, *}$, Esti Mumpuni ${ }^{2}$, Kevin Sandy ${ }^{3}$ \\ ${ }^{1}$ Bidang Kimia, Fakultas Farmasi, Universitas Pancasila, Jagakarsa, Jakarta Selatan \\ ${ }^{2}$ Bidang Kimia Medisinal, Fakultas Farmasi, Universitas Pancasila, Jagakarsa, Jakarta Selatan \\ ${ }^{3}$ Fakultas Farmasi, Universitas Pancasila, Jagakarsa, Jakarta Selatan \\ *email korespondensi: estimulatsari@gmail.com
}

Received : 15 Juli 2019; Revised : 26 September 2019; Accepted : 28 Oktober 2019; Published : 31 Oktober 2019

\begin{abstract}
ABSTRAK
Tanaman Annonaceae adalah familia dengan 800 spesies yang tersebar di seluruh dunia. Beberapa penelitian menunjukkan bahwa Annonaceae memiliki aktivitas biologis sebagai antikanker dan telah digunakan sebagai obat herbal secara empiris. Pada penelitian ini dilakukan penapisan virtual beberapa struktur senyawa dari tanaman familia Annonaceae. Tujuan penelitian ini adalah untuk menganalisis dan memperoleh kandidat senyawa yang aktif sebagai ligan pada reseptor estrogen alfa yang dapat memicu timbulnya kanker payudara, selanjutnya akan dilakukan elusidasi moda ikatan senyawa representatif aktif dan inaktif untuk melihat interaksi asam-asam amino pada binding site senyawa tersebut. Penelitian ini menggunakan protokol tervalidasi hasil penelitian Anita, Radifar, Kardono, Hanafi, \& Istyastono, 2012, dengan berbagai aplikasi komputasi seperti SPORES, PLANTS, BKchem, OpenBabel dan PyMol. Hasil penapisan virtual menunjukkan bahwa dari 39 kandidat senyawa ada 18 senyawa dari tanaman familia Annonaceae yang memiliki nilai ChemPLP lebih kecil daripada ligan pembanding, artinya ada 18 senyawa yang memiliki afinitas yang lebih baik terhadap reseptor sehingga dapat mencegah timbulnya kanker payudara.
\end{abstract}

Kata-kata kunci : Annonaceae; estrogen alfa; kanker; penapisan virtual

\section{PENDAHULUAN}

Kanker payudara memiliki tingkat prevalensi tertinggi di Indonesia. Kanker tersebut paling sering dialami wanita pasca menopause, yakni ketika ovarium tidak lagi memproduksi estrogen. Pasca menopause, tubuh akan memproduksi estrogen di jaringan lemak, termasuk di dalam payudara. Jaringan payudara mengandung sel-sel lemak yang memproduksi enzim aromatase yang memproduksi estrogen. Pada jaringan payudara normal, kadar aromatase masih terkontrol. Semakin tua seorang wanita, sel-sel lemak di payudara cenderung akan menghasilkan enzim aromatase dalam jumlah yang besar sehingga meningkatkan kadar estrogen lokal. Estrogen yang diproduksi secara lokal inilah yang diyakini berperan dalam memicu kanker payudara pada wanita pasca menopause (Allred, Brown, \& Medina, 2004).

Tanaman familia Annonaceae yang telah digunakan sebagai obat herbal secara empiris dan beberapa penelitian menyatakan sebagian tanaman dari familia Annonaceae memiliki aktivitas sebagai antikanker payudara (Rachmani, Suhesti, Widiastuti \& Aditiyono, 2012). Namun belum ada penjelasan terkait senyawa apa yang berperan aktif sebagai penghambat reseptor estrogen alpha dan bagaimana interaksi ligand - reseptornya. Pada penelitian ini dilakukan uji aktivitas secara in silico (komputasi) untuk mengetahui senyawa-senyawa aktif atau inaktif sebagai ligan pada reseptor estrogen alfa (ER- $\alpha$ ). Beberapa aplikasi yang digunakan antara lain BKChem 0.13.0, Structure PrOtonation and Recognition System (SPORES), Protein-Ligand ANT System (PLANTS) versi 1.2, Python-Enchanced Molecular Graphics Tool (PyMOL), Open Babel versi 2.3.0, R Computational Statistics versi 2.14.0 (Korb O \& Exner 2006 ; Purnomo H, 2011; Pranowo H.D., 2009; molmod.org) dan menggunakan protokol docking yang telah tervalidasi hasil penelitian (Anita, Radifar, Kardono, Hanafi, \& Istyastono, 2012).

Uji secara in silico (penapisan virtual) mengurangi secara signifikan jumlah senyawa-senyawa kimia yang perlu disintesis. Hal ini memberi efek positif karena jumlah senyawa untuk diuji aktivitas biologisnya secara in vitro maupun in vivo juga akan berkurang. Selain itu, metode ini berguna untuk memberikan pengetahuan awal tentang jenis ikatan senyawa obat sebagai ligan dengan makromolekul tertentu. Dari penelitian ini diharapkan dapat diketahui senyawa - senyawa dalam tanaman familia Annonaceae yang aktif 
maupun tidak aktif sebagai ligan penghambat reseptor estrogen alfa sehingga mampu mencegah timbulnya kanker.

\section{EKSPERIMEN}

\section{Alat dan Bahan}

Model gambar 2D 39 struktur kimia dari senyawa yang terkandung pada tanaman familia Annonaceae sebagaimana ditunjukkan pada Tabel 1 (John B, 2010), model gambar 2D senyawa ZINC 01914469 dan senyawa dimer nomor 11 (4-[4-hydroxy-3-(prop-2-en-1-yl)-phenyl]-2-(prop-2-en-1-yl)phenol) yang dijadikan sebagai senyawa pembanding dan senyawa rujukan yang merupakan hasil dari penelitian Anita, Radifar, Kardono, Hanafi, \& Istyastono (2012), struktur kristal reseptor estrogen alfa (ER- $\alpha$ ) dengan kode pdb 3ERT.

\section{Instrumen}

Sistem operasi Linux Ubuntu 10.04 LTS http://releases.ubuntu.com/lucid/., BKChem 0.13.0 dari http://www.bkchem.zirael.org, Structure PrOtonation and Recognition System (SPORES) dari http://www.tcd.uni-konstanz.de/research/spores.php, Protein-Ligand ANT System (PLANTS) versi 1.2 http://www.tcd.uni-konstanz.de/index.php, Python-Enchanced Molecular Graphics Tool (PyMOL) dari http://www.pymol.org., Open Babel versi 2.3.0 dari http://www.openbabel.org, $R$ Computational Statistics versi 2.14.0, Laptop Acer Aspire V5-4 471 G, processor Intel ${ }^{\circledR}$ Core $^{\mathrm{TM}}$ i3-3227U CPU @1,90 GHz, NVIDIA GeForce $710 M 4 G B, R A M 4 G B, H D D 500$ GB.

\section{Preparasi Ligand (Senyawa Uji)}

Sebanyak 39 bentuk struktur 2D senyawa uji digambar dengan program MarvinSketch. Kemudian dioptimasi protonation dengan metode Major Microspecies. Selanjutnya dilakukan optimasi konformasi dengan menggunakan metode conformers, untuk mendapat pose konformasi dengan energi minimum.

\section{Preparasi Protein Target (Reseptor)}

File dari protein target (reseptor estrogen alfa human MCF-7 breast cancer cells) dengan kode 3ERT.pdb di load dari file pdb ke YASARA. Kemudian dihapus bagian dari sistem yang tidak diperlukan dalam protocol docking. Tambahkan hidrogen ke dalam dengan cara (Edit>Add>Hydrogen to: all). Simpan file sebagai YASARA Object (File>Save as>YASARA Object>nama reseptor.yob) Selanjutnya hapus ligand asli sehingga hanya menyisakan protein target dengan sisi (pocket) untuk berikatan dengan senyawa uji (docking) (Edit>Delete>Residue); Pilih Name BEZ, Belongs to or has All, klik "OK", dan simpan file sebagai protein.mol2. Koordinat pocket dapat diketahui dengan merujuk pada koordinat ligand 3D asli.

\section{Proses Docking Senyawa Uji (Pengikatan Senyawa Uji dengan Reseptor / Protein Target)}

Pada Terminal (Pendrivelinux-KDE) digunakan protokol identifikasi ligan reseptor estrogen tervalidasi oleh Anita, Radifar, Kardono, Hanafi, \& Istyastono (2012). dengan model command line interface (CLI). Kemudian dibuat directory kerja uji-er dan berkas - berkas hasil preparasi Anita, Radifar, Kardono, Hanafi, \& Istyastono (2012) disalin ke directory kerja tersebut. Selanjutnya dibuat aplikasi uji-er dengan nama uji-er.sh yang berupa shell script yang berii baris - baris perintah. File yang dihasilkan dibuat executable (chmod $\mathrm{u}+\mathrm{x}$ uji-er.sh) untuk selajutnya dijalankan dengan perintah /uji-er.sh. Jendela aplikasi BKChem akan muncul dan masing-masing senyawa uji pada Gambar 1, digambar dalam bentuk 2 dimensi dan di-export dengan nama file: uji.mol. Setelah itu aplikasi uji-er.sh secara otomatis akan menjalankan protokol hasil validasi Anita, Radifar, Kardono, Hanafi, \& Istyastono (2012) dan memberikan hasil berupa nilai Chem PLP yang tersimpan dengan nama file: hasil.txt. Nilai Chem PLP merupakan nilai akumulasi energy bebas, energy Selain nilai senyawa uji, pada file hasil tersebut terdapat nilai ChemPLP senyawa pembanding. Selanjutnya dilakukan elusidasi moda ikatan senyawa representatif dengan menggunakan aplikasi PyMOL untuk mengetahui asam amino yang berada dalam binding pocket reseptor.

\section{HASIL DAN DISKUSI}

Penapisan Virtual Senyawa Tanaman Familia Annonaceae 
Senyawa dari tanaman familia Annonaceae diuji secara in silico menggunakan protokol penapisan virtual tervalidasi milik Anita, Radifar, Kardono, Hanafi, \& Istyastono (2012). Protokol tersebut menghasilkan nilai Enrichment Factor 1\% (EF1\%) sebesar 21,2. EF1\% merupakan kemampuan protokol untuk mengidentifikasi persen True Positive (TP) pada 1\% False Positive (FP) dimana artinya protokol penapisan virtual tersebut sudah dapat diterima dan layak digunakan menurut kriteria jurnal (Huang, Shoichet, Irwin, \& Francisco, 2006) untuk penapisan virtual senyawa yang berpotensi sebagai antagonis reseptor estrogen.

Hasil penapisan virtual senyawa uji ditunjukkan pada Tabel 1. Nilai hasil perhitungan simulasi docking senyawa dari tanaman familia Annonaceae (senyawa uji) dibandingkan dengan nilai senyawa pembanding ZINC 01914469 menunjukkan bahwa terdapat 18 senyawa yang aktif sebagai ligan pada reseptor estrogen alfa (ER- $\alpha$ ) dan 21 senyawa inaktif. Delapan belas senyawa aktif tersebut antara lain senyawa Asimin, Asiminecin, Asiminocin,Cohibin B, Cohibin D, Giganenin, Gigantriocin, Goniocin, Goniodenin, Montacin, Mucosin, Murisolin, Parviflorin, Rollimucin, Rollinacin, Squamocin B, Trilobacin, dan Trilobin. Senyawa - senyawa uji tersebut dinyatakan aktif karena memiliki nilai Chem PLP lebih kecil dari senyawa pembanding ZINC 01914469. Nilai Chem PLP terkecil berdasarkan hasil uji in silico yaitu senyawa Asiminocin dengan nilai $-132.087 \pm 0.0195$ sehingga senyawa ini dapat disarankan untuk dikembangkan dan diteliti lebih lanjut sebagai agonis atau antagonis terhadap ER- $\alpha$. Nilai Chem PLP dibuat berdasarkan energi bebas Gibbs sehingga semakin kecil (makin negatif) nilai Chem PLP maka dapat dikatakan memiliki potensi yang baik yang menunjukkan bahwa senyawa tersebut lebih mudah dan stabil dalam berikatan dengan reseptor dibanding senyawa pembanding. Semakin mudah dan stabil nya suatu senyawa dengan reseptor semakin besar kemampuannya dalam menginhibisi protein dalam memproduksi estrogen, sehingga diperkirakan semakin besar kemampuan senyawa dalam mencegah timbulnya kanker.

Tabel 1. Hasil penapisan virtual senyawa uji menggunakan aplikasi uji-er.sh dengan senyawa pembanding

\begin{tabular}{|c|c|c|c|}
\hline \multirow{2}{*}{$\begin{array}{c}\text { Nama } \\
\text { Senyawa Uji }\end{array}$} & \multicolumn{2}{|c|}{ Nilai Chem $P L P \pm S D$} & \multirow{2}{*}{$\begin{array}{l}\text { Aktivitas Ligan terhadap ER- } \alpha \\
\text { (in silico) }\end{array}$} \\
\hline & Senyawa uji & Senyawa Pembanding (ZINC 01914469) & \\
\hline Acetogenin & $-112.612 \pm 2.1952$ & $-123.739 \pm 3.1329$ & (-) tidak aktif \\
\hline Annonacin & $-122.248 \pm 3.8125$ & $-123.724 \pm 27.1859$ & (-) tidak aktif \\
\hline Annonacinon & $940.484 \pm 1.0708$ & $-123.998 \pm 4.3018$ & (-) tidak aktif \\
\hline Argentinin & $-85.6917 \pm 0.3435$ & $-124.315 \pm 1.4582$ & (-) tidak aktif \\
\hline Asimilobin & $-117.98 \pm 1.9589$ & $-122.643 \pm 1.29$ & (-) tidak aktif \\
\hline Asimin & $-121.408 \pm 2.8188$ & $-118.097 \pm 2.1183$ & $(+)$ aktif \\
\hline Asiminecin & $-127.238 \pm 0.0173$ & $-118.302 \pm 3.5068$ & $(+)$ aktif \\
\hline Asiminocin & $-132.087 \pm 0.0195$ & $-116.51 \pm 2.3748$ & $(+)$ aktif \\
\hline Asitrocin & $-121.593 \pm 3.2463$ & $-124.443 \pm 0.9533$ & (-) tidak aktif \\
\hline Bullatacin & $-122.096 \pm 1.2146$ & $-122.335 \pm 4.4371$ & (-) tidak aktif \\
\hline Cohibin B & $-127.694 \pm 0.5458$ & $-124.066 \pm 3.6019$ & $(+)$ aktif \\
\hline Cohibin D & $-127.461 \pm 2.8937$ & $-118.895 \pm 3.6719$ & $(+)$ aktif \\
\hline Giganenin & $-120.718 \pm 3.565$ & $-114.042 \pm 0.9208$ & (+) aktif \\
\hline Gigantriocin & $-118.844 \pm 0.4978$ & $-117.551 \pm 1.4579$ & $(+)$ aktif \\
\hline Glaucin & $-72.1205 \pm 1.0023$ & $-116.976 \pm 2.6401$ & (-) tidak aktif \\
\hline Goniocin & $-119.651 \pm 1.4763$ & $-117.268 \pm 2.4736$ & $(+)$ aktif \\
\hline Goniodenin & $-126.01 \pm 0.0716$ & $-119.398 \pm 2.3982$ & $(+)$ aktif \\
\hline Goniothalamicin & $-113.763 \pm 1.0232$ & $-116.472 \pm 2.7522$ & (-) tidak aktif \\
\hline Magnolin & $-92.1678 \pm 0.2356$ & $-116.329 \pm 0.8582$ & (-) tidak aktif \\
\hline Montacin & $-121.975 \pm 0.65$ & $-115.683 \pm 3.2617$ & $(+)$ aktif \\
\hline Motrilin & $-118.031 \pm 5.8804$ & $-119.341 \pm 4.3514$ & (-) tidak aktif \\
\hline Mucosin & $-123.005 \pm 2.0098$ & $-118.287 \pm 3.2104$ & $(+)$ aktif \\
\hline Muricatacin & $-85.4934 \pm 1.9044$ & $-117.702 \pm 3.8749$ & (-) tidak aktif \\
\hline Muricatalin & $-114.72 \pm 0.0204$ & $-117.715 \pm 1.9354$ & (-) tidak aktif \\
\hline Muricatin A & $-120.043 \pm 3.4993$ & $-121.982 \pm 2.2775$ & (-) tidak aktif \\
\hline Muricin A & $-116.793 \pm 1.9881$ & $-121.719 \pm 3.418$ & (-) tidak aktif \\
\hline Murisolin & $-123.541 \pm 4.5163$ & $-122.012 \pm 4.0595$ & $(+)$ aktif \\
\hline Oxopurpurein & $-70.3165 \pm 0.1271$ & $-117.76 \pm 3.1698$ & (-) tidak aktif \\
\hline Parviflorin & $-124.772 \pm 1.8854$ & $-118.434 \pm 3.8618$ & $(+)$ aktif \\
\hline P-Coumaric Acid & $-70.0891 \pm 1.085$ & $-119.014 \pm 0.8447$ & (-) tidak aktif \\
\hline Rollimucin & $-121.713 \pm 1.9708$ & $-116.955 \pm 0.8997$ & $(+)$ aktif \\
\hline Rollinacin & $-125.18 \pm 2.4201$ & $-118.436 \pm 3.9078$ & $(+)$ aktif \\
\hline Romucosin I & $-82.261 \pm 2.7756$ & $-122.067 \pm 2.5999$ & (-) tidak aktif \\
\hline Squamocin B & $-120.096 \pm 2.1033$ & $-118.378 \pm 1.5272$ & $(+)$ aktif \\
\hline
\end{tabular}


Jurnal Sains dan Edukasi Sains, Vol.2, No.2, Agustus 2019: 70-76

\begin{tabular}{lccc}
\hline \multicolumn{1}{c}{ Nama } & \multicolumn{2}{c}{ Nilai Chem PLP \pm SD } \\
\multicolumn{1}{c}{ Senyawa Uji } & Senyawa uji & Senyawa Pembanding (ZINC 01914469) & $\begin{array}{c}\text { Aktivitas Ligan terhadap ER- } \alpha \\
\text { (in silico) }\end{array}$ \\
\hline Sylvaticin & $-112.95 \pm 2.6901$ & $-118.456 \pm 1.3091$ & $(-)$ tidak aktif \\
Trilobacin & $-128.152 \pm 0.8319$ & $-124.192 \pm 0.7591$ & $(+)$ aktif \\
Trilobin & $-125.309 \pm 1.6274$ & $-124.368 \pm 1.3084$ & $(+)$ aktif \\
\hline
\end{tabular}

\section{Elusidasi Moda Ikatan}

Elusidasi moda ikatan digunakan untuk mengetahui asam amino - asam amino dalam reseptor yang berperan aktif di dalam binding pocket reseptor. Elusidasi ini dilakukan dengan memanfaatkan aplikasi PyMOL. Langkah ini dilakukan untuk melihat interaksi asam-asam amino dalam binding site senyawa representatif aktif maupun tidak aktif. Terdapat residu asam-asam amino pada senyawa representatif aktif yang tidak terdapat pada senyawa representatif tidak aktif, residu asam amino tersebut berpengaruh terhadap antagonis reseptor estrogen alfa $(E R-\alpha)$ senyawa representatif aktif. Menurut hasil penelitian Anita, Radifar, Kardono, Hanafi, \& Istyastono (2012) asam amino yang diduga berperan penting terhadap afinitas senyawa terhadap reseptor estrogen alfa (ER- $\alpha$ ) yaitu GLU353, ARG394, ASP351 dan THR347. Pada penelitian ini peroleh hasil bahwa residu asam amino pada senyawa representatif aktif terhadap reseptor estrogen alfa (ER- $\alpha$ ) berbeda-beda pada tiap senyawa aktif. Secara umum residu asam amino yang terikat pada senyawa representative aktif tapi tidak terikat pada senyawa representative inaktif antara lain GLU353, ARG394, ASP351 dan THR347. Hal ini sejalan dengan hasil penelitian Anita, Radifar, Kardono, Hanafi, \& Istyastono (2012). Secara keseluruhan, residu asam amino yang berikatan dengan senyawa uji dapat ditunjukkan pada Tabel 2.

Tabel 2. Asam amino yang berinteraksi dengan senyawa uji yang representatif aktif dan inaktif

\begin{tabular}{|c|c|}
\hline Nama Senyawa & Jenis Asam Amino yang Berinteraksi \\
\hline Asimin (aktif) & $\begin{array}{l}\text { ALA350, ASP351, ARG394, CYS530, GLU353,GLY521, ILE424, LEU345, LEU354, LEU384 LEU391, } \\
\text { LEU428, LEU525, LEU539, MET342, MET388, MET421, MET522, PHE404, THR347, TRP383 }\end{array}$ \\
\hline Asimine & $\begin{array}{l}\text { ALA350, ASP351, ARG394,CYS530 GLU353, ILE424, LEU345, LEU354, LEU384, LEU391, LEU428, } \\
\text { LEU525, LEU539, MET342, MET388, MET421, MET522, PHE404, THR347, TRP383, TYR526 }\end{array}$ \\
\hline Asimin & $\begin{array}{l}\text { ALA350, ASP351, ARG394, CYS530, GLU353, GLY420, GLY521, HIS524, ILE424, LEU345, LEU384, } \\
\text { LEU391, LEU428, LEU525, LYS520, LEU539, MET342, MET388, MET421, MET522, PHE404, THR347, } \\
\text { TRP383, TYR526 }\end{array}$ \\
\hline Cohibin & $\begin{array}{l}\text { ALA350, ASP351, ARG394, GLU353, GLY521, ILE424, LEU345, LEU384, LEU391, LEU428, LEU525, } \\
\text { LEU539, MET342, MET388, MET421, MET522, PHE404, THR347, TRP383 }\end{array}$ \\
\hline Cohibi & $\begin{array}{l}\text { ALA350, ASP351, ARG394, CYS530, GLU353,GLY521, ILE424, LEU345, LEU354, LEU384, LEU391, } \\
\text { LEU428, LEU525, LEU539, MET342, MET388, MET421, MET522, PHE404, THR347, TRP383, TYR526 }\end{array}$ \\
\hline Gigan & $\begin{array}{l}\text { ALA350, ASP351, ARG394, CYS530, GLU353, ILE424, LEU345, LEU384 LEU391, LEU428, LEU525, } \\
\text { LEU539, MET342, MET388, MET421, MET522, PHE404, THR347, TRP383, TYR526 }\end{array}$ \\
\hline Gigan & $\begin{array}{l}\text { ALA350, ASP351, ARG394, CYS530 GLU353, GLU419, GLY420, GLY521, HIS524, ILE424, LEU345, } \\
\text { LEU354, LEU384, LEU391,LEU428, LEU525,LEU539, MET342, MET388, MET421, MET522, PHE404, } \\
\text { THR347, TRP383, TYR526 }\end{array}$ \\
\hline Goniocir & $\begin{array}{l}\text { ALA350, ASP351, ARG394, CYS530 GLU353, GLY521, HIS524, ILE424, LEU345, LEU354, LEU384, } \\
\text { LEU391, LEU428, LEU525, LYS520, LEU539, MET342, MET388, MET421, MET522, PHE404, THR347, } \\
\text { TRP383, TYR526 }\end{array}$ \\
\hline Goniodenin (aktif) & $\begin{array}{l}\text { 51, ARG394, CYS530, GLU353, ILE424, LEU345, LEU354, LEU384, LEU391, LEU428, } \\
\text { 0, LEU539, MET342, MET388, MET421, MET522, PHE404, THR347, TRP383, TYR526 }\end{array}$ \\
\hline Montacin (aktif) & $\begin{array}{l}\text { ALA350, ASP351, ARG394, CYS530, GLU353, GLY420, GLY521, HIS524, ILE424, LEU345, LEU384, } \\
\text { LEU391, LEU428, LEU525, LYS520, LEU539, MET342, MET388, MET421, MET522, PHE404, THR347, } \\
\text { TRP383, TYR526, VAL416 }\end{array}$ \\
\hline Mucosin (aktif) & $\begin{array}{l}\text { ALA350, ASP351, ARG394,CYS530, GLU353, ILE424, LEU345, LEU354, LEU384, LEU391, LEU428, } \\
\text { LEU525, LYS520, LEU539, MET342, MET388, MET421, MET522, PHE404, THR347, TRP383, TYR526 }\end{array}$ \\
\hline Muriso & $\begin{array}{l}\text { ALA350, ASP351, ARG394, CYS530, GLU353, ILE424, LEU345, LEU354, LEU384, LEU391, LEU428, } \\
\text { LEU525, LYS520, LEU539, MET342, MET388, MET421, MET522, PHE404, THR347, TRP383, TYR526 }\end{array}$ \\
\hline Parviflo & $\begin{array}{l}\text { ALA350, ASP351, ARG394, CYS530, GLU353, ILE424, LEU345, LEU354, LEU384, LEU391, LEU428, } \\
\text { LEU525, LYS520, LEU539, MET342, MET388, MET421, MET522, PHE404, THR347, TRP383, TYR526 }\end{array}$ \\
\hline Rollir & $\begin{array}{l}\text { ALA350, ASP351, ARG394, CYS530, GLU353, GLU386, GLY521, HIS524, ILE424, LEU345, LEU384, } \\
\text { LEU391, LEU428, LEU525, LYS520, LEU539, MET342, MET388, MET421, MET522, PHE404, THR347, } \\
\text { TRP383, TYR526 }\end{array}$ \\
\hline acin (aktif) & $\begin{array}{l}\text { ALA350, ASP351, CYS530 GLU353, ILE424, LEU345, LEU354, LEU384, LEU391, LEU428, LEU525, } \\
\text { LYS520, LEU539, MET342, MET388, MET421, MET522, PHE404, THR347, TRP383, TYR526 }\end{array}$ \\
\hline
\end{tabular}




\begin{tabular}{ll}
\hline Nama Senyawa & Jenis Asam Amino yang Berinteraksi \\
\hline Squamocin B & ALA350, ASP351, ARG394, CYS530, GLU353, ILE424, LEU345, LEU354, LEU384, LEU391, LEU428, \\
(aktif) & LEU525, LYS520, LEU539, MET342, MET388, MET421, MET522, PHE404, THR347, TRP383, TYR526 \\
\hline Trilobacin (aktif) & ALA350, ASP351, ARG394, CYS530 GLU353, GLU419, GLY420, GLY521, HIS524, ILE424, LEU345, \\
& LEU354, LEU384, LEU391, LEU428, LEU525, LYS520, LEU539, MET342, MET388, MET421, MET522, \\
& PHE404, THR347, TRP383, TYR526 \\
\hline Trilobin (aktif) & ALA350, ASP351, ARG394, CYS530, GLU353, GLU419, GLY420, GLY521, HIS524, ILE424, LEU345, \\
& LEU384, LEU391, LEU428, LEU525, LEU539, MET342, MET388, MET421, MET522, PHE404, THR347, \\
& TRP383 \\
\hline Annonacinon & ALA350, ASP351, ARG394, CYS530, LEU345, LEU384, LEU391, LEU408, LEU428, LYS520, MET342, \\
(tidak aktif) & MET38, MET421, MET522, PHE404, SER395, THR347, TRP383, VAL392 \\
\hline
\end{tabular}

\section{Visualisasi Interaksi Senyawa Uji dengan Reseptor}

Senyawa uji yang dipilih untuk divisualisasikan dengan menggunakan menggunakan software PyMOL dilakukan berdasarkan nilai Chem PLP. Senyawa yang dipilih ialah senyawa representatif aktif tertinggi (asiminocin) dengan nilai Chem PLP paling negatif dan senyawa representatif tidak aktif terendah (annonacinon). Gambar 3D dengan aplikasi PyMOL ditunjukkan Gambar 1 dan 2.
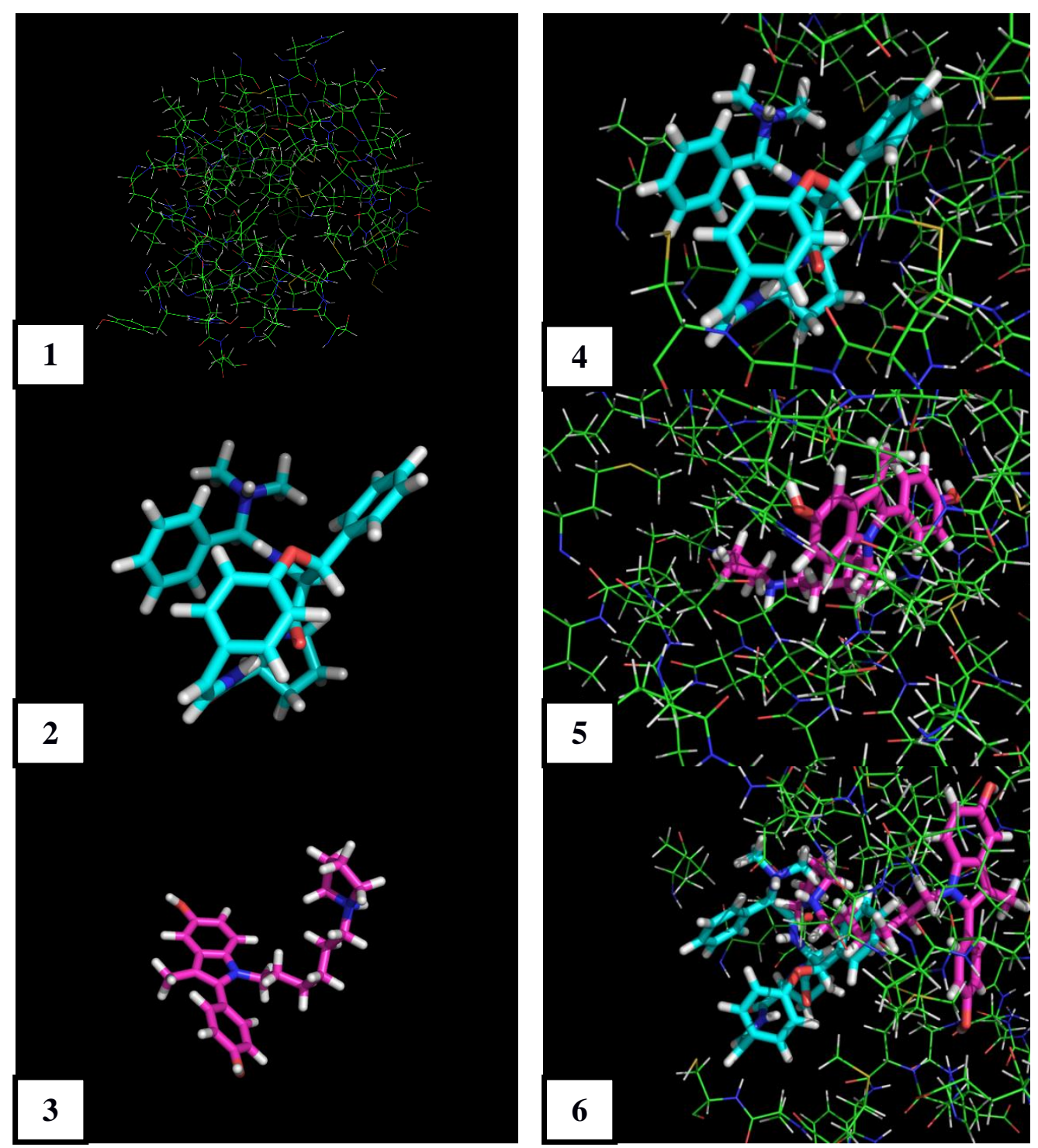

Gambar 1. (1) Struktur protein_bindingsite_fixed.mol2, (2) Struktur 3D dari senyawa Asiminocin (mode sticks), (3) Struktur 3D senyawa pembanding ZINC01914469 (mode sticks), (4) Pose 3D senyawa Asiminocin di dalam protein_bindingsite_fixed.mol2, (5) Pose 3D senyawa pembanding ZINC 01914469 di dalam protein_bindingsite_fixed.mol2, (6) Overlay senyawa Asiminocin dengan senyawa pembanding ZINC 01914469 di dalam protein_bindingsite_fixed.mol 

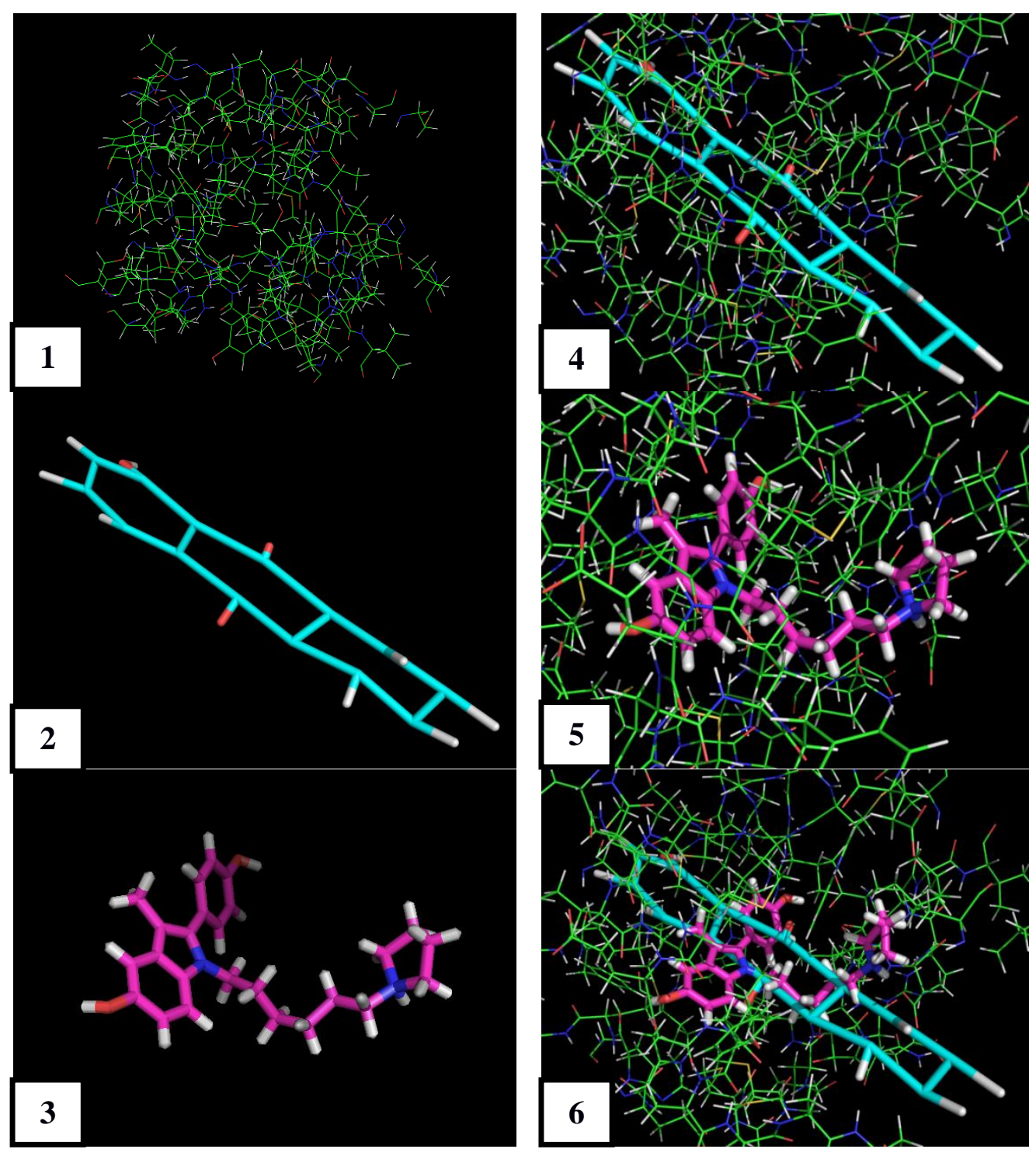

Gambar 2. (1) Struktur protein_bindingsite_fixed.mol2, (2) Struktur 3D dari senyawa Annonacinon (mode sticks), (3) Struktur 3D senyawa pembanding ZINC01914469 (mode sticks), (4) Pose 3D senyawa Annonacinon di dalam protein_bindingsite_fixed.mol2, (5) Pose 3D senyawa pembanding ZINC 01914469 di dalam protein_bindingsite_fixed.mol2, (6) Overlay senyawa Annonacinon dengan senyawa pembanding ZINC 01914469 di dalam protein_bindingsite_fixed.mol2

Gambar 1 menunjukkan bahwa senyawa Asiminocin memiliki bentuk struktur yang hampir menyerupai senyawa pembanding (ZINC 01914469) sehingga senyawa uji tersebut memiliki afinitas dan ikatan yang hampir sama dengan senyawa pembanding sebagai ligan pada reseptor estrogen alfa (ER- $\alpha$ ). Gambar 2 menunjukkan bahwa senyawa annonacinon memiliki bentuk struktur yang sangat berbeda dan lebih besar dibandingkan senyawa pembanding (ZINC 01914469). Hal ini mengakibatkan afinitas dan ikatan senyawa Annonacinon pada reseptor berbeda dengan senyawa pembanding. Semakin mirip afinitas dan ikatan senyawa uji dengan ligan pembanding maka semakin baik interaksi senyawa uji dengan reseptor, energi ikatan semakin kecil (Chem PLP semakin negatif) sehingga interaksi semakin mudah terjadi dan ikatan lebih stabil (afinitas tinggi) Semakin mudah dan stabil nya suatu senyawa berikatan dengan reseptor maka semakin besar kemampuan senyawa tersebut dalam menginhibisi protein untuk memproduksi estrogen. Hal ini menyebabkan semakin besar kemampuan senyawa dalam mencegah timbulnya kanker.

\section{KESIMPULAN}

Senyawa dari tanaman familia Annonaceae yang aktif sebagai ligan terhadap reseptor estrogen alfa $(E R-\alpha)$ antara lain: asimin, asiminecin, asiminocin, cohibin $\mathrm{B}$, cohibin $\mathrm{D}$, giganenin, gigantriocin, gonionin, goniodenin, montacin, mucosin, murisolin, parviflorin, rollimucin, rollinacin, squamocin $B$, trilobacin, dan trilobin. Senyawa yang memiliki aktivitas terbaik sebagai ligan pada ER- $\alpha$ adalah senyawa Asiminocin dari tanaman Asimina triloba. Dari hasil elusidasi moda ikatan senyawa representative mengindikasikan bahwa 
interaksi dengan residu-residu asam amino seperti GLU 353, ARG394, ASP351, dan THR347 diduga dapat meningkatkan afinitas sebagai ligan pada reseptor estrogen alfa (ER- $\alpha$ ). Afinitas yang meningkat dapat meningkatkan kemampuan dalam mencegah timbulnya kanker.

\section{UCAPAN TERIMA KASIH}

Terima kasih penulis sampaikan kepada Enade Perdana Istyastono, Ph.D., Apt yang telah memberi banyak arahan dan bimbingan untuk terseleseikannya penelitian ini.

\section{DAFTAR PUSTAKA}

Allred, D. C., Brown, P., \& Medina, D. (2004). The origins of estrogen receptor alpha-positive and estrogen receptor alpha-negative human breast cancer, 6(6), 240-245. https://doi.org/10.1186/bcr938

Anita, Y., Radifar, M., Kardono, L. B., Hanafi, M., \& Istyastono, E. P. (2012). Structure-based design of eugenol analogs as potential estrogen receptor antagonists. Bioinformation, 8(19), 901-906. https://doi.org/10.6026/97320630008901

Huang, N., Shoichet, B. K., Irwin, J. J., \& Francisco, S. (2006). Benchmarking Sets for Molecular Docking, 6789-6801.

http://molmod.org/2010/02/07/pemilihan-sistem-operasi-dan-aplikasi-pemodelan-molekul/ diakses pada tanggal 21 September 2015 pukul 20.21 WIB.

http://releases.ubuntu.com/lucid/diakses pada tanggal 21 September 2015 pukul 20.35 WIB.

http://www.bkchem.zirael.org/ diakses pada tanggal 21 September 2015 pukul 20.47 WIB.

http://www.openbabel.org, diakses pada tanggal 21 September 2015 pukul 20.35 WIB.

http://www.pymol.org., diakses pada tanggal 21 September 2015 pukul 20.35 WIB.

http://www.rcsb.org/pdb/files/3ERT.pdb.gz)

http://www.tcd.uni-konstanz.de/research/spores.php diakses pada tanggal 21 September 2015 pukul 20.35 WIB.

http://www.tcd.uni-konstanz.de/index.php diakses pada tanggal 21 September 2015 pukul 20.35 WIB.

John, Buckingham. (2010). Dictionary of Natural Products on DVD, Taylor \& Francis Ltd, ver 19:1

Korb O, St T, Exner TE. PLANTS : Application of Ant Colony Optimization to Structure-Based Drug Design. 2006;247-58.

Pranowo H.D. (2009). Peran kimia komputasi dalam desain molekul obat. Yogyakarta; 2009.

Purnomo H. (2011). Kimia Komputasi: Molecular docking PLANTS (Protein Ligand Ant System). Yogyakarta: Pustaka Pelajar1.

Rachmani, Suhesti, Widiastuti \& Aditiyono (2012).The Breast Of Anticancer From Leaf Extract Of Annona Muricata Againts Cell Line In T47d, Int J of App Sci Tech, (2) 1. 